\title{
ANALISIS YURIDIS TERHADAP ANAK DI BAWAH UMUR YANG MENDUDUKI JABATAN DEWAN KOMISARIS MENURUT UNDANG-UNDANG NOMOR 40 TAHUN 2007 TENTANG PERSEROAN TERBATAS
}

\author{
Oleh \\ Retno Susilowati dan Agus Maulana*)
}

\section{Abstrak}

Berdasarkan Pasa1 1 angka 1 Undang-Undang Nomor 40 Tahun 2007 tentang Perseroan Terbatas, bahwa Perseroan Terbatas adalah badan hukum yang merupakan persekutuan modal, didirikan berdasarkan perjanjian, melakukan kegiatan usaha dengan modal dasar yang seluruhnya terbagi dalam saham, dan memenuhi persyaratan yang ditetapkan dalam undang-undang. Persekutuan modal yang dimaksud adalah harta/aset PT harus berasal dari minimal 2 (dua) orang pemegang saham yang tidak terjadi percampuran harta kekayaan. Namun, di dalam kehidupan bermasyarakat terdapat pendirian PT yang salah satu pemegang sahamnya adalah anak di bawah umur dan menjabat sebagai Dewan Komisaris dalam PT tersebut. Para pemegang saham dalam PT Y adalah orang tua dan anaknya yang masih di bawah umur serta harta kekayaan PT Y dianggap berasal dari 1 (satu) orang pemegang saham saja, sudah jelas dalam segi yuridis hal tersebut melanggar ketentuan Pasal 1320 ayat (2) KUHPerdata, Pasal 1313 KUHPerdata serta Pasal 110 juncto Pasal 112 Undang-Undang Nomor 40 Tahun 2007 tentang Perseroan Terbatas karena tidak terjadi persekutuan modal yang sesungguhnya. Dengan demikian, PT Y harus menambah 1 (satu) orang pemegang saham/investor lainnya agar menghindari pertanggungjawaban tidak terbatas.

\section{Kata Kunci : Perseroan Terbatas, Dewan Komisaris}

\section{A.PENDAHULUAN}

Pesatnya perkembangan bisnis di Indonesia dapat membawa keuntungan bagi negara dan berdampak positif bagi pembangunan nasional, namun dalam setiap aktivitas bisnis terdapat aturanaturan dan/atau kaidah-kaidah yang mengatur yang bertujuan agar aktivitas bisnis dapat berjalan dengan lancar dan sebagaimana mestinya, serta pelaku bisnis dapat merasa aman dan nyaman dalam bertransaksi. Dengan adanya aturan-aturan dan/atau kaidah-kaidah yang disebut hukum bisnis. Hukum bisnis adalah suatu perangkat kaidah

*) Penulis adalah Dosen Fakultas Hukum

Universitas Islam Syekh Yusuf hukum yang mengatur tentang tata cara pelaksanaan urusan atau kegiatan dagang, industri, atau keuangan yang dihubungkan dengan produksi atau pertukaran barang atau jasa dengan menempatkan uang dari pra entrepreneur dalam risiko tertentu dengan usaha tertentu dan bertujuan untuk mendapatkan ketuntungan.

Badan hukum atau korporasi adalah ciptaan hukum yang menunjuk pada suatu badan, di mana terhadap badan hukum diberi status sebagai subjek hukum, di samping manusia sebagai subjek hukum yang alamiah. Sekalipun diciptakan oleh hukum, badan ini dapat 
menjalankan segala tindakan hukum. Segala harta kekayaan yang timbul dari perbuatan itu harus dipandang sebagai harta kekayaan badan, terlepas dari pribadi-pribadi manusia yang terhimpun di dalamnya. Jika dari perbuatan itu timbul kerugian, maka atas kerugian itupun dipandang harus dapat dipertanggungjawabkan semata-mata dengan harta kekayaan yang terhimpun dalam badan yang bersangkutan. Begitu pula jika terjadi perbuatan yang merugikan pihak lain, maka untuk mempermudah menunjuk siapa diantara sekian banyak orang yang tergabung di dalamnya, secara yuridis mengkonstruksikan badan itulah sebagai subjek hukum yang harus dipertanggungjawabkan. ${ }^{1}$

Salah satu bentuk badan usaha yang banyak diminati pengusaha adalah badan usaha yang berbadan hukum Perseroan Terbatas (PT). Dahulu namanya Naamloze Vennotschap (company limited by shares), sudah tidak asing lagi terdengar di telinga masyarakat Indonesia dan Perseroan Terbatas merupakan persekutuan modal yang dibentuk atas dasar kesepakatan para pendirinya yang menyertakan modal dalam bentuk uang dengan bukti kepemilikan haknya berupa saham-saham yang dikeluarkan oleh Perseroan Terbatas.

Dasar hukum tentang Perseroan Terbatas di Indonesia mulanya telah diatur dalam Kitab Undang-undang Hukum Dagang (KUHD)/ Wetboek van Koophandel $(W v K)$, namun saat ini sudah diatur dengan undang-undang tersendiri, yaitu Undang-Undang Nomor 40 Tahun 2007 tentang Perseroan Terbatas.

Bertitik tolak dari singkatnya ketentuan yang mengatur Perseroan dalam KUHD, maka Pasal 1 KUHD sendiri menegaskan berlakunya KUH Perdata

${ }^{1}$ Rudy Prasetyo, Perkembangan Korporasi Dalam Proses Modernisasi Dan Penyimpanganpenyimpangannya, Undip Press, Semarang, 2009, hlm. 8. dalam bidang hukum dagang. Keterkaitan antara KUHD dan KUH Perdata sangat erat hubungannya, hal ini sebagaimana dijelaskan dalam Pasal 1 KUHD yang menyatakan:

Pasal 1 KUHD:

"Kitab undang-undang Hukum Perdata berlaku juga bagi hal-hal yang diatur kitab undang-undang ini, sekadar di dalam kitab undang-undang ini tidak diatur secara khusus menyimpang". 2

Dari ketentuan Pasal 1 KUHD tersebut dapat disimpulkan bahwa sangat singkat pengaturan mengenai Perseroan Terbatas di Indonesia, yang dibuktikan bahwa KUH Perdata juga menjadi dasar hukum untuk Perseroan Terbatas dan hal tersebut menjelaskan bahwa pengaturan Perseroan Terbatas di Indonesia belum ada kepastian hukum. Pada tahun 1995, diterbitkan Undang-Undang Nomor 1 tahun 1995 tentang Perseroan Terbatas. ${ }^{3}$

Penerbitan Undang-Undang Nomor 1 tahun 1995 tentang Perseroan Terbatas tidak serta merta tanpa adanya alasan yang jelas, hal tersebut dilakukan karena KUHD dianggap tidak lagi sesuai dengan perkembangan ekonomi dan dunia usaha yang semakin pesat, baik secara nasional maupun internasional dan pemerintah ingin menciptakan kesatuan (unification) hukum untuk badan usaha berbentuk badan hukum khususnya Perseroan Terbatas.

Tepatnya pada tanggal 16 Agustus 2007, dilahirkannya Undang-Undang Nomor 40 tahun 2007 tentang Perseroan Terbatas ("UUPT") yang mencabut ketentuan-ketentuan yang diatur dalam Undang-Undang Nomor 1 Tahun 1997, artinya bahwa pengaturan tentang Perseroan Terbatas telah diperbaharui bahkan hingga saat ini masih berlaku serta

2 M. Yahya Harahap, Hukum Perseroan Terbatas, Sinar Grafika, Jakarta, 2009. hlm. 21-22.

3 Ibid., hlm. 24. 
dijadikan dasar hukum bagi Perseroan Terbatas di Indonesia.

Pada dasarnya, Perseroan Terbatas didirikan oleh 2 (dua) orang pendiri atau lebih, karena Perseroan Terbatas merupakan persekutuan modal yang didirikan berdasarkan perjanjian. Berdasarkan Pasal 1 butir 1 UUPT, yang berbunyi:

"Perseroan Terbatas adalah badan hukum yang merupakan persekutuan modal, didirikan berdasarkan perjanjian, melakukan kegiatan usaha dengan modal dasar yang seluruhnya terbagi dalam saham, dan memenuhi persyaratan yang ditetapkan dalam undang-undang ini serta peraturan pelaksanaannya."

Sebagai badan hukum, Perseroan Terbatas memiliki karakteristik yang berbeda dari badan usaha yang berbadan hukum maupun yang tidak berbadan hukum lainnya, ciri khas badan hukum Perseroan Terbatas, antara lain:

1. Adanya kekayaan yang terpisah dari kekayaan pribadi masing-masing pemegang saham (shareholder);

2. Tanggung jawab pemegang saham terbatas, artinya mereka hanya bertanggung jawab terhadap penyertaan modal yang dimasukkan ke dalam Perseroan;

3. Adanya organisasi teratur;

4. Mempunyai maksud dan tujuan tertentu;

5. Mempunyai kepentingan sendiri;

6. Status pendiriannya harus mendapat pengesahan dari Menteri Hukum dan Hak Asasi Manusia Republik Indonesia (cq. Ditjen AHU).

7. Adanya pengurus (Direksi) dan pengawas (Dewan Komisaris) yang merupakan satu kesatuan pengurus dan pengawas terhadap perseroan dan tanggung jawabnya terbatas pada tugasnya, yang harus sesuai dengan anggaran dasar atau keputusan
Rapat Umum Pemegang Saham (RUPS). ${ }^{4}$

Perseroan Terbatas didirikan berdasarkan perjanjian, sehingga unsurunsurnya harus mengikuti ketentuanketentuan dan syarat-syarat perjanjian antara lain persesuaian kehendak antara para pihak, yaitu bertemunya antara penawaran dan penerimaan. Sementara itu, kecakapan adalah kemampuan menurut hukum untuk melakukan perbuatan hukum (perjanjian). Kecakapan ini ditandai dengan dicapainya umur 21 (dua puluh satu) tahun atau telah menikah, walaupun usianya belum mencapai 21 (dua puluh satu) tahun, adanya objek tertentu, objek perjanjian harus jelas, di samping itu juga mengenai suatu sebab yang halal juga merupakan syarat tentang isi perjanjian yang berarti bahwa isi perjanjian tersebut tidak bertentangan dengan undang-undang, kesusilaan dan ketertiban umum. ${ }^{5}$

Dalam kasus penelitian ini terdapat suatu perusahaan Perseroan Terbatas yang salah satu pemegang sahamnya adalah seorang anak yang masih di bawah umur dan anak tersebut sekaligus menjabat sebagai Dewan Komisaris dalam Perseroan, serta status pendirian Perseroan tersebut telah memperoleh Surat Keputusan pengesahan dari Menteri Hukum dan Hak Asasi Manusia Republik Indonesia sejak tahun 2014, sehingga jelas dari segi yuridis telah melanggar ketentuan Pasal 110 juncto Pasal 112 UUPT, mengenai pengangkatan Dewan Komisaris, yaitu disyaratkan bahwa seseorang yang dapat diangkat menjadi

\footnotetext{
${ }^{4}$ http://artonang.blogspot.com/2016/02/uns ur-unsur-perseroan-terbatasnaamloze.html diakses pada tanggal 4 Maret 2019, pukul 19.45 WIB.

5 Ahmadi Miru dan Sakka Pati, Hukum Perikatan: Penjelasan Makna Pasal 1233 sampai 1456 BW, Cetakan 7, Rajawali Pers, Jakarta, 2016, hlm. 67-69.
} 
anggota Dewan Komisaris adalah orang perseorangan yang cakap melakukan perbuatan hukum. Keberadaan PT tersebut dianggap tidak sah, mengingat adanya cacat hukum dalam akta pendiriannya.

Dari uraian di atas, penulis merumuskan permasalahan sebagai berikut :

1. Bagaimana akibat hukum status dan permasalahan yang timbul terhadap anak di bawah umur yang menjadi pemegang saham (shareholder) sekaligus menjabat sebagai Dewan Komisaris dalam suatu Perseroan Terbatas menurut Undang-Undang Nomor 40 tahun 2007 tentang Perseroan Terbatas?

2. Bagaimana tanggung jawab terhadap pemegang saham oleh anak di bawah umur dalam kasus pendirian PT Y berdasarkan akta Nomor 1, tanggal 5 Desember 2014?.

\section{B. PEMBAHASAN}

1. Akibat Hukum Status dan Permasalahan yang Timbul Terhadap Anak di bawah Umur yang menjadi Pemegang Saham sekaligus Menjabat sebagai Dewan Komisaris dalam suatu Perseroan Terbatas menurut Undang-Undang Nomor 40 Tahun 2007 tentang Perseroan Terbatas

Pengertian Perseroan Terbatas menurut Pasal 1 angka 1 Undang-Undang Nomor 40 Tahun 2007 tentang Perseroan Terbatas, yang berbunyi:

"Perseroan Terbatas, yang selanjutnya disebut Perseroan adalah badan hukum yang merupakan persekutuan modal, didirikan berdasarkan perjanjian, melakukan kegiatan usaha dengan modal dasar yang seluruhnya terbagi dalam saham dan memenuhi persyaratan yang ditetapkan dalam Undang-Undang ini serta peraturan pelaksanaannya."
Dari kutipan pasal tersebut di atas, kalimat "didirikan berdasarkan perjanjian", yang berarti setiap PT harus didirikan dengan dasar perjanjian berupa kesepakatan yang dibuat para pendirinya.

Suatu perjanjian dapat dikatakan sah apabila telah memenuhi unsur-unsur dalam ketentuan Pasal 1320 KUHPerdata tentang syarat-syarat sahnya perjanjian, yang berbunyi:

"Untuk sahnya perjanjian-perjanjian, diperlukan empat syarat:

1. kesepakatan mereka yang mengikatkan dirinya;

2. kecakapan untuk membuat suatu perikatan;

3. suatu hal tertentu;

4. suatu sebab yang halal."

Ayat (1) dan ayat (2) dalam Pasal 1320 KUHPerdata disebut syarat subyektif, sedangkan ayat (3) dan ayat (4) disebut syarat obyektif. Apabila tidak terpenuhinya salah salah satu unsur dari keempat unsur tersebut menyebabkan cacat dalam perjanjian, dan perjanjian tersebut dapat diancam dengan kebatalan, baik dapat dibatalkan (jika terdapat pelanggaran terhadap unsur subyektif), maupun batal demi hukum (dalam hal tidak terpenuhinya unsur obyektif), dengan pengertian bahwa perikatan yang lahir dari perjanjian tersebut tidak dapat dipaksakan pelaksanaannya.

Menurut Pasal 1330 KUHPerdata terdapat limitasi orang-orang yang dinyatakan tidak cakap dalam melakukan perjanjian, yaitu sebagai berikut:

1. Anak yang belum dewasa

Dikatakan anak yang belum dewasa, yaitu anak di bawah umur yang belum mencapai usia 21 (dua puluh satu) tahun dan belum terikat dalam suatu ikatan perkawinan ketentuan hukum adat maupun peraturan perundang-undangan yang berlaku di Indonesia. 
2. Perempuan yang telah kawin

Setelah terbitnya Undang-Undang Nomor 1 Tahun 1974 tentang Perkawinan, maka perempuan yang telah kawin dapat membuat suatu perjanjian dengan syarat harus memperoleh persetujuan dari suaminya.

Dalam kasus penelitian ini, Tuan A (selaku ayah dari Tuan C) dan Tuan C (anak di bawah umur dari Tuan A dan Nyonya B) telah mendirikan suatu Perseroan Terbatas bernama PT Y. Singkatnya, Tuan A bersekutu dengan Tuan C untuk mendirikan PT Y, hal tersebut jelas melanggar ketentuan Pasal 1320 ayat (1) juncto 1330 KUHPerdata, karena masih di bawah umur, Tuan $\mathrm{C}$ belum diperbolehkan untuk membuat dan/atau melakukan perjanjian. Tuan $\mathrm{C}$ selaku pendiri telah mengambil bagian saham sebesar 1.530 (seribu lima ratus tiga puluh) saham, dengan nominal seluruhnya sebesar Rp. 153.000.000,- (seratus lima puluh tiga juta Rupiah).

Pada dasarnya, orang tua yang hidup terlama dapat menjadi wali yang sah bagi anaknya yang masih di bawah umur, selama ia tidak dicabut kekuasaannya sebagai wali, hal tersebut tertuang dalam ketentuan Pasal 345 KUHPerdata, yang berbunyi:

"Apabila salah satu dari kedua orang tua meninggal dunia, maka perwalian terhadap anak-anak yang belum dewasa, demi hukum dipangku oleh orang tua yang hidup terlama, sekadar ini tidak dibebaskan atau dipecat dari kekuasaan orang tuanya."

Oleh karena itu, segala sesuatu yang diatur dalam Anggaran Dasar, sebagaimana dimaksud dalam Akta Pendirian PT Y, Nomor 1, tertanggal 5 Desember 2014, dalam hal menghadiri, menandatangani RUPS untuk meminjam dan/atau menjaminkan aset Perseroan ataupun menandatangani akta-akta yang diperlukan, Tuan $\mathrm{C}$ harus diwakili oleh orang tuanya, baik Tuan A maupun Nyonya B selama mereka tidak dicabut kekuasaannya sebagai orang tua.

Menurut Penulis, hal tersebut tidak dapat dibenarkan sepenuhnya, karena di antara mereka mempunyai satu kepentingan, yang dibuktikan dengan persatuan dan/atau percampuran harta kekayaan antara Tuan A, Nyonya B dan Tuan C, sedangkan PT merupakan persekutuan modal. Oleh karena itu, apabila Tuan C tetap berkeinginan menjadi pemegang saham dalam PT Y, maka PT Y harus melakukan RUPS Luar Biasa untuk memasukkan 1 (satu) orang atau investor lain untuk menjadi pemegang saham dalam PT Y, dengan demikian pemegang saham PT Y menjadi 3 (tiga) orang. Apabila tidak dilakukan perubahan susunan pemegang saham PT Y, maka atas segala kerugian yang dialami Perseroan menjadi tanggung jawab secara pribadi Tuan A dan/atau Nyonya B, karena ia merupakan orang tua/wali dari Tuan $\mathrm{C}$, sebagaimana diatur dalam Pasal 7 ayat (5) dan ayat (6) UUPT.

Akibat lain dari pendirian PT yang salah satu pemegang sahamnya masih di bawah umur adalah pihak-pihak yang berkepentingan dapat mengajukan permohonan pembubaran terhadap PT Y ke pengadilan negeri setempat. Hal ini tidak menutup kemungkinan pihak bank swasta yang menolak pengajuan kredit PT $\mathrm{Y}$, membuat permohonan pembubaran ke pengadilan negeri setempat, dalam hal ini Pengadilan Negeri Tangerang di Tangerang. Apabila pihak yang berkepentingan tersebut tidak mengajukan permohonan pembubaran, maka PT Y akan tetap ada serta dapat melakukan kegiatan usaha ataupun tindakan hukum lainnya. Akan tetapi, tanggung jawab terhadap segala kerugian yang dialami Perseroan, akan menjadi tanggung jawab pribadi para pemegang saham.

Mengenai syarat pengangkatan Dewan Komisaris dalam suatu Perseroan 
Terbatas telah diatur dalam Pasal 110 ayat (1) juncto Pasal 112 Undang-Undang Nomor 40 Tahun 2007 tentang Perseroan Terbatas, yang berbunyi:

\section{Pasal 110 ayat (1)}

“(1) Yang dapat diangkat menjadi anggota Dewan Komisaris adalah orang perseroangan yang cakap melakukan perbuatan hukum, kecuali dalam waktu 5 (lima) tahun sebelum pengangkatannya pernah:

a. dinyatakan pailit;

b. menjadi anggota Direksi atau anggota Dewan Komisaris yang dinyatakan bersalah menyebabkan suatu Perseroan dinyatakan pailit; atau

c. dihukum karena melakukan tindak pidana yang merugikan keuangan negara dan/atau yang berkaitan dengan sektor keuangan."

\section{Pasal 112}

“(1) Pengangkatan anggota Dewan Komisaris yang tidak memenuhi persyaratan sebagaimana dimaksud dalam Pasal 110 ayat (1) dan ayat (2) batal karena hukum sejak saat anggota Dewan Komisaris lainnya atau Direksi mengetahui tidak terpenuhinya persyaratan tersebut.

(2) Dalam jangka waktu paling lambat 7 (tujuh) hari terhitung sejak diketahui, Direksi harus mengumumkan batalnya pengangkatan anggota Dewan Komisaris yang bersangkutan dalam Surat Kabar dan memberitahukannya kepada menteri untuk dicatat dalam daftar Perseroan.

(3) Perbuatan hukum yang telah dilakukan oleh anggota Dewan Komisaris sebagaimana dimaksud pada ayat (1) untuk dan atas nama Dewan Komisaris sebelum pengangkatannya batal, tetap mengikat dan menjadi tanggung jawab Perseroan.

(4) Ketentuan sebagiamana dimaksud pada...."

Dalam kasus ini, akta pendirian PT Y telah memperoleh pengesahan dari Menteri Hukum dan HAM Republik Indonesia, sebagaimana ternyata dari Surat Keputusan, Nomor AHU-40234.40.10.2014, tertanggal 18 Desember 2014, sebagaimana diatur dalam Pasal 7 ayat (4) Undang-Undang Nomor 40 Tahun 2007 tentang Perseroan Terbatas, yang berbunyi:

"Perseroan memperoleh status badan hukum pada tanggal diterbitkannya Keputusan Menteri mengenai pengesahan badan hukum Perseroan."

Akan tetapi, pengangkatan Tuan C menjadi Dewan Komisaris dalam PT Y dinyatakan batal demi hukum, yang berarti pengangkatannya dianggap tidak pernah terjadi karena bertentangan dengan Pasal 110 ayat (1) juncto Pasal 112 Undang-Undang Nomor 40 Tahun 2007 tentang Perseroan Terbatas, sehingga dalam jangka waktu 7 (tujuh) hari, sejak Tuan A mengetahui batalnya pengangkatan anggota Dewan Komisaris, harus melakukan RUPS Luar Biasa dengan mata acara perubahan susunan pengurus Perseroan, dengan memasukkan Nyonya $\mathrm{B}$ ataupun orang lain yang dikehendaki serta memenuhi syarat pengangkatan Dewan Komisaris untuk menggantikan Tuan C sebagai Dewan Komisaris dalam PT Y.

Seperti yang telah dijelaskan, bahwa Dewan Komisaris mempunyai tugas pengawasan terhadap Direksi perseroan dalam hal melakukan perbuatan hukum atas nama perseroan. Tugas pengawasan inilah yang harus dilaksanakan dengan itikad baik dan penuh kehati-hatian. Inilah yang merupakan fiduciary duty Dewan Komisaris terhadap perseroan. Sedikit berbeda dari Direksi yang mewakili perseroan dalam tindakan ke luar, Dewan 
Komisaris dalam tugas pengawasannya sama sekali tidak melakukan fungsi perwakilan. 6

Penulis berpendapat bahwa hal tersebut merupakan suatu kekeliruan yang cukup fatal yang dilakukan oleh Notaris D (selaku pembuat akta pendirian PT Y) dalam melaksanakan tugasnya sebagai pejabat umum, ia tidak memberikan legal advice tentang siapa yang seharusnya menjadi pemegang saham dalam PT Y dan layak untuk menjabat sebagai anggota Dewan Komisaris dalam Perseroan sesuai dengan ketentuan Undang-Undang Nomor 40 Tahun 2007 tentang Perseroan Terbatas.

Akibat hukum selanjutnya, Penulis menganalisis bahwa anggota Dewan Komisaris PT Y tidak memenuhi kriteria dan persyaratan yang ditetapkan baik dari UUPT, anggaran dasar perseroan maupun peraturan-peraturan terkait (masih di bawah umur), sehingga secara hukum keberadaan PT Y tersebut tidak mendapatkan kepercayaan dari lembaga keuangan.

Hal ini jelas terjadi dalam praktik, bahwa pada saat PT Y mengajukan kredit untuk menambah modal kerja kepada salah satu bank swasta, namun permohonan pengajuan kredit tersebut ditolak dengan alasan Nyonya B selaku wali dari Tuan $\mathrm{C}$ belum memiliki penetapan pengangkatan wali dari pengadilan, dan apabila terjadi cidera janji dan/atau kredit macet pihak bank akan mengalami kesulitan untuk mengeksekusi jaminan yang akan diberikan.

Akibat yang lain dari pendirian PT Y, menurut Penulis PT Y dapat dibubarkan oleh pihak-pihak yang berkepentingan apabila dalam operasional perusahaan mengakibatkan kerugian terhadap pihak

6 Gunawan Widjaja, Risiko Hukum sebagai Direksi, Komsaris \& Pemilik $P T$, Cetakan ke-II, Forum Sahabat, Jakarta, 2008, hlm. 88. lain, karena para pemegang saham dalam PT Y masih terjadi percampuran/persatuan harta kekayaan, sehingga pemegang saham dalam PT Y dianggap kurang dari 2 (dua) orang.

\section{Tanggung Jawab Terhadap Peme- gang Saham oleh Anak di Bawah Umur Dalam Kasus Pendirian PT Y Berdasarkan Akta Nomor 1, tanggal 5 Desember 2014}

Dalam hal pemegang saham masih di bawah umur yang menjadi pemegang saham dalam suatu perseroan terbatas, maka yang bertanggung jawab sepenuhnya adalah orang tua pemegang saham tersebut. Secara logika, anak di bawah umur tidak memiliki penghasilan kecuali karena warisan/hibah maupun wasiat, akan tetapi pengurusan atas harta kekayaan yang diperoleh tersebut dilakukan oleh orang tua yang hidup terlama sepanjang orang tua sang anak tidak dicabut kekuasaannya sebagaimana dinyatakan dalam Pasal 345 KUHPerdata.

Dalam kasus penelitian ini, Tuan C yang masih di bawah umur diberikan saham oleh orang tuanya, yaitu Tuan A, dengan demikian aset PT $\mathrm{Y}$ berupa saham-saham merupakan miliki pribadi Tuan A tanpa terkecuali. Sehingga, apabila perseroan mengalami kerugian baik karena kesalahan dan/atau kelalaian yang dilakukan oleh Tuan A ataupun tidak merupakan tanggung jawab pribadi Tuan A sepenuhnya, sehingga harta bersama antara Tuan A dan Nyonya B turut menjadi jaminan untuk pelunasan utangutang PT Y.

Hal tersebut terjadi karena pada dasarnya aset yang dimiliki PT Y berasal dari Tuan A saja, sedangkan Tuan A dan Tuan C merupakan ayah dan anak (di bawah umur), sehingga terjadi percampuran atas harta kekayaan antara Tuan A dengan Tuan C. Dengan demikian, persekutuan modal yang diamanatkan dalam Pasal 1 angka 1 UUPT 2007 tidak terjadi 
di dalam pendirian PT Y. Sehingga, tanggung jawabnya diperluas menjadi tanggung jawab tidak terbatas.

Menurut Penulis, konsekuensi adanya tanggung jawab tidak terbatas apabila perseroan mengalami kerugian, wanprestasi dan/atau pailit, maka bukan hanya harta perseroan saja yang menjadi jaminannya, melainkan seluruh harta kekayaan pribadi para pemegang sahamnya untuk melunasi seluruh kewajiban-kewajiban yang harus diselesaikan oleh perseroan.

\section{PENUTUP}

PT berdasarkan ketentuan Pasal 7 ayat (1) Undang-Undang Nomor 40 Tahun 2007 tentang Perseroan Terbatas, disyaratkan bahwa pendirian PT harus didirikan berdasarkan perjanjian oleh minimal 2 (dua) orang atau lebih, artinya bahwa apabila PT didirikan oleh suami-istri tanpa adanya pemisahan harta, maka PT tersebut dianggap hanya mempunyai 1 (satu) pemegang saham, karena suamiistri tersebut masih terjadi percampuran harta kekayaan, sehingga tidak terjadi persekutuan modal.

Hal tersebut berlaku juga jika pemegang sahamnya adalah ayah/ibu dengan 1 (satu) orang anak yang statusnya masih di bawah umur, karena harta anak yang masih di bawah umur merupakan satukesatuan dengan harta orang tuanya dan perbuatan hukum dari anak yang masih di bawah umur harus diwakili oleh orang tuanya baik ayah maupun ibunya sebagai wali dari anaknya tersebut.

Pendirian PT Y tidak ada larangan terhadap status harta milik bersama atau tidak bagi pemegang saham, karena para pemegang saham merupakan satu keluarga, meskipun salah satu pemegang sahamnya masih di bawah umur, di mana status harta merupakan milik bersama, kecuali ada perjanjian pemisahan atas harta kekayaan para pemilik/ pendirinya.

Mengenai tidak adanya pemisahan harta bersama dalam PT Y, maka dalam hal suami sebagai Direksi perseroan bertang-gung jawab secara pribadi atas kerugian-kerugian perseroan apabila karena kesalahan atau kelalaiannya dalam menjalankan tugasnya, sehingga harta bersama itulah turut menjadi jaminan untuk pelunasan utang-utang PT Y. Tuan C sebagai pemegang saham sekaligus Dewan Komisaris PT Y, tidak memenuhi kriteria dan persyaratanpersyaratan yang ditentukan, misalnya tidak melakukan fit \& proper test/uji kepatutan dan kelayakan, melanggar UU No.40/2007 tentang PT, anggaran dasar dan peraturan-peraturan terkait. Tuan C belum memiliki integritas, kompetensi dan reputasi yang baik, hal ini mengingat bahwa sebagai Dewan Komisaris dituntut untuk dapat bertindak secara pribadi yang independen, sehingga harus memiliki ilmu pengetahuan yang memadai, kemampuan dan komitmen yang tinggi, sehingga dapat menjalankan tugasnya dengan baik, karena tugas tersebut sangat berat, yaitu berhubungan dengan pengawasan dan memberikan nasihatnasihat dan saran atas berbagai kebijakan dan langkah-langkah yang diambil oleh Direksi perseroan dalam menjalankan perusahaan.

Setiap Notaris pembuat akta autentik atau akta yang mempunyai pembuktian sempurna di muka pengadilan, harus melaksanakan tugas sesuai dengan kode etik profesinya dan sumpah jabatan Notaris. Seharusnya, Notaris D menyarankan agar Nyonya B mengisi jabatan sebagai anggota Dewan Komisaris dalam PT Y bukan Tuan C yang notabenenya adalah seorang anak di bawah umur. Untuk semua Notaris, hendaknya wajib untuk memberikan legal advice sesuai dengan ketentuan peraturan perundangundangan bagi para pendiri Perseroan 
Terbatas maupun orang lain yang akan membuat suatu perjanjian di hadapan Notaris. Dimungkinkan para pendiri atau orang lain tersebut tidak mengerti atau mengetahui aturan-aturan yang berkaitan dengan perjanjian yang akan dibuatnya agar tidak bertentangan dengan peraturan-peraturan hukum yang berlaku.

PT Y seharusnya segera memasukkan minimal 1 (satu) orang pemegang saham baru dan/atau investor lain yang dikehendaki untuk menjadi pemegang dalam PT Y, agar terjadinya "persekutuan modal" yang sesungguhnya dan hal ini untuk menghindari pertanggungjawaban secara pribadi bila terjadi kerugian, wanprestasi dan/atau dipailitkan.

Seharusnya Notaris D menyarankan kepada orang tua/wali dari Tuan $\mathrm{C}$ agar mengajukan permohonan penetapan pengadilan pada pengadilan negeri setempat mengenai pengangkatan wali. Hal tersebut dilakukan untuk dapat menguatkan perwalian sebagaimana tercantum dalam Akta Pendirian PT Y, Nomor 1, tanggal 5 Desember 2014.

\section{DAFTAR PUSTAKA}

\section{A. Literatur}

Harahap, Yahya M. Hukum Perseroan Terbatas. Jakarta, Sinar Grafika, 2009.

Miru, Ahmadi, Pati, Sakka. Hukum Perikatan: Penjelasan Makna Pasal 1233 sampai 1456 BW. Jakarta, Rajawali Pers, 2016.

Prasetyo, Rudy, Perkembangan Korporasi Dalam Proses Modernisasi dan Penyimpangan-penyimpangannya. Semarang, Undip Press, 2009.
Widjaja, Gunawan, Risiko Hukum sebagai Direksi, Komisaris \& Pemilik PT. Jakarta, Forum Sahabat, 2008.

\section{B. Sumber Hukum Lain}

http://artonang.blogspot.com/2016/02/ unsur-unsur-perseroan-terbatasnaamloze.html, diakses pada tanggal 4 Maret 2019, pukul 19.45 WIB 